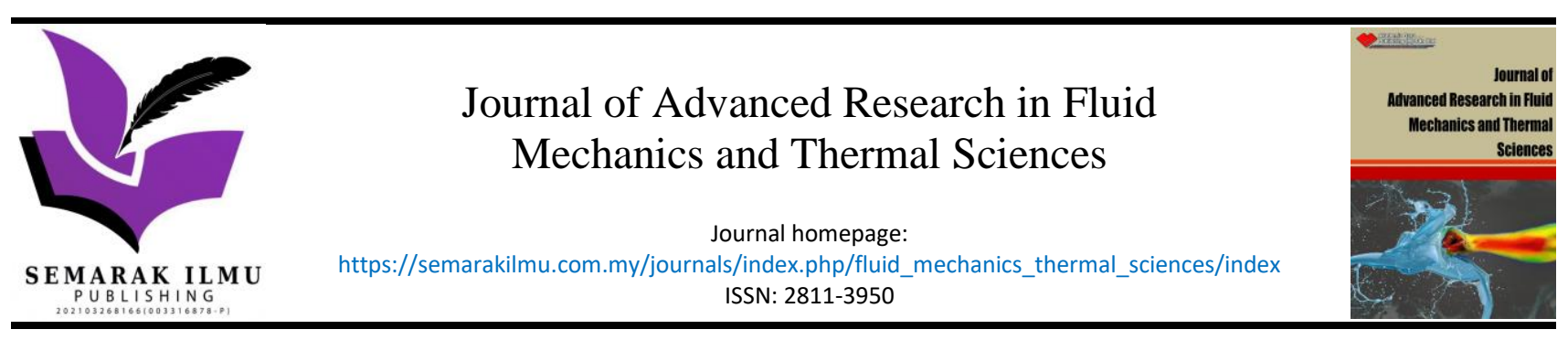

\title{
Investigation and Analysis of Air Curtains for the Improvement of Refrigeration Energy Efficiency
}

\author{
Peem Pongsupat ${ }^{1}$, Juntakan Taweekun ${ }^{1 *}$, Piyanut Saengsikhiao ${ }^{2}$ \\ Energy Technology Program, Faculty of Engineering, Prince of Songkla University, Hatyai, Songkhla 90100, Thailand \\ Department of Mechanical and Mechatronics Engineering, Faculty of Engineering, Prince of Songkla University, Hatyai, Songkhla 90112 Thailand
}

\section{ARTICLE INFO}

\section{Article history:}

Received 9 October 2021

Received in revised form 3 January 2022

Accepted 6 January 2022

Available online 9 February 2022

Keywords:

CFD; FCU; Cold room; Air curtain; Common grille; Honeycomb grille

\section{ABSTRACT}

\begin{abstract}
The purpose of this research is to present a warm air infiltration simulation for a cold room, considering the effects of an air curtain. At present, there exist a large number of retail businesses, operating within an industry entailing high investment and competition. Therefore, retail operators must distinguish factors that are essential to lowering their costs, one of which is energy reduction. A survey of energy consumption in stores found that most used energy is due to the cooling system. Therefore, we tested the protection of cold rooms against air inflow by conducting three simulations: 1 . Without an air curtain; 2 . using an air curtain having a common grille; and 3 . using an air curtain with a honeycomb grille. The cold room temperature was set to $1^{\circ} \mathrm{C}$, the cold room door was $200 \times 100 \mathrm{~m}^{2}$, and the air curtain was installed $5 \mathrm{~cm}$ above the cold room door; furthermore, the velocity of air emitted from the air curtain was $6.5 \mathrm{~m} / \mathrm{s}$. Warm air infiltration simulations were carried out using SolidWorks Flow Simulation software, in order to determine the temperature change in the cold room and the airflow direction. From the results of the comparative experiments, when using the different wind grilles, there were differences in the infiltration of warm air. The honeycomb grille reduced air turbulence in the cold room more effectively than the common grille. As a result, the temperature in the cold room was consistent, and the temperature inside the cold room was maintained $10.62 \%$ lower when using a honeycomb grille compared to a common grille.
\end{abstract}

\section{Introduction}

Retail businesses continue to grow, in order to meet the needs of customers who have increasingly turned to retail during the coronavirus pandemic. Retail business entails both investment and high competition. The cost of energy used for cooling to preserve food is the highest cost of electricity for a store. Therefore, much research has been conducted regarding how to save energy in the field of refrigeration, including the development of environmentally friendly and energy efficient refrigerants, the development of glass doors for open freezers to save energy, the adoption of digital scroll compressors to enhance compressor performance, and so on. In Figure 1, the energy

\footnotetext{
* Corresponding author

Email-address: juntakan.t@psu.ac.th

https://doi.org/10.37934/arfmts.92.1.212225
} 
consumption test results for 30 stores in Taiwan are shown. There are many reasons for the high energy consumption of cooling systems, including poorly insulated walls, overheating of electrical equipment inside a cold room, or the infiltration of warm air from the outside.

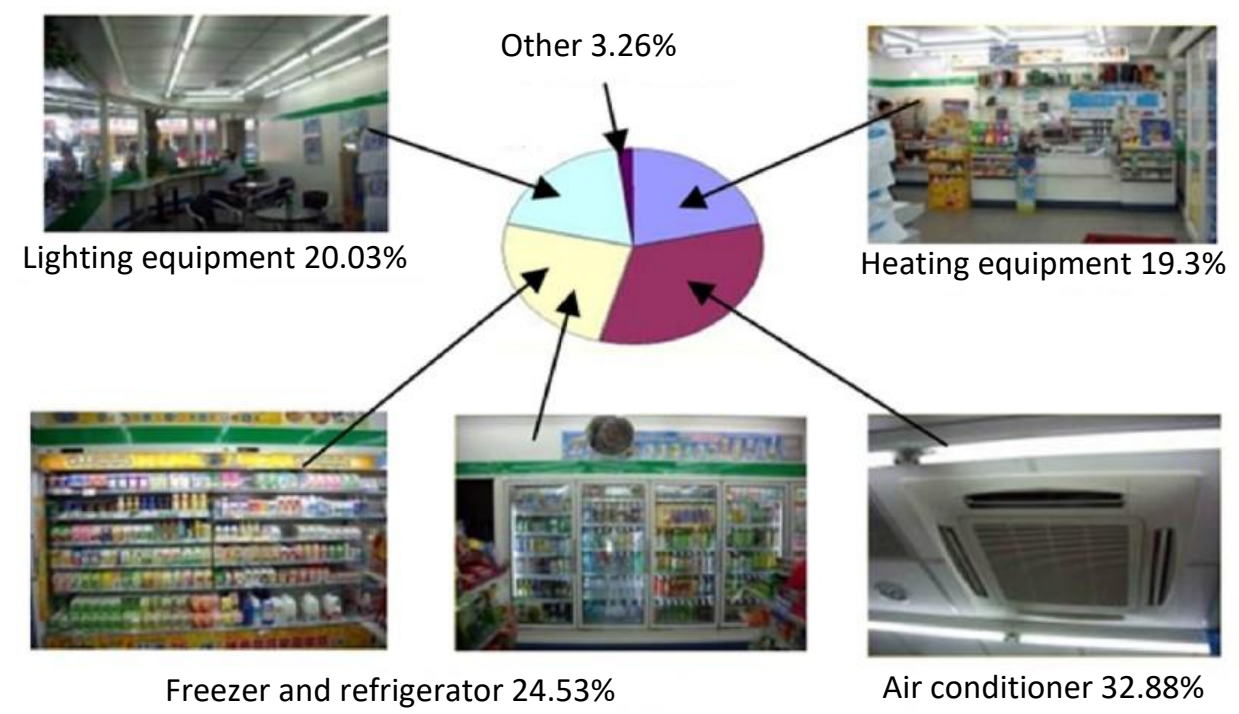

Fig. 1. Proportion of energy consumption in convenience stores in Taiwan [1]

Large retailers in Thailand can be divided into three categories: 1 . Department stores; 2 . discount stores; and 3. supermarkets. The number of large retail stores exceeded 1000 in 2018, and has been increasing every year. These retailers have higher energy consumption, in terms of cooling, as a cold room is needed for preserving foods. As such, retailers that require cold rooms are among the most energy-intensive stores. One of the reasons for this is the loss of cooling due to opening of the cold room door. This may cause more heat to be brought in from the outside, and requires energy for cooling to recover from the temperature loss. Previous experiments have found that the infiltration of warm air through the cold room door accounts for approximately half of the total cooling load in cold rooms [12-17].

In response to such problems, a door curtain can be applied to the door to reduce the infiltration of warm air; however, door curtains can disrupt the loading and unloading of products, cause the accumulation of dirt, and require regular maintenance, as the curtain can be easily torn during the handling of materials [10]. Alternatively, an air curtain should be used to prevent the infiltration of warm air [11]. When the air curtain is installed, it can lead to energy savings of up to $48 \%$ [6].

Research objectives, air curtains that use a conventional air grille may enable more air to disperse, as the grille cannot effectively organize the wind that comes out; in this case, the efficiency of the air curtain may be reduced. In consideration of the above, a honeycomb grille can be used to replace a conventional grille, in order to organize the wind before it leaves the grille and increase the efficiency of the air curtain.

Air curtain research has shown that performance improvements can be made to prevent the infiltration of warm air from outside of the cold room as much as possible, considering factors such as the installation position, wind speed, wind angle, and so on. For example, Figure 4 compares the effect of installation of an air curtain in a refrigerated truck. When the air curtain is installed, it can lead to energy savings of up to $48 \%$ [6]. The air velocity that is suitable for an air curtain installed over a door with a height of $2 \mathrm{~m}$, during the first 30 seconds, is $5 \mathrm{~m} / \mathrm{s}$ [9]. Comparing the installation position of the air curtain between the inside and outside of the refrigerated truck, the installation 
of an outer air curtain showed a slightly better effect [7]. The air curtain grille, with an angle between $0^{\circ}$ and $10^{\circ}$, should face the front room at an angle of $10^{\circ}$ at a wind speed of $4 \mathrm{~m} / \mathrm{s}$; in this way, it can save more than $17.6 \%$ of energy [8]. As shown in Figure 2, for a cabinet opening with a height of 1200 $\mathrm{mm}$, a wind speed of $2.6 \mathrm{~m} / \mathrm{s}$ can prevent the air curtain from breaking [2]. The appropriate location to install the air curtain for a cold room is at a door height of $1.36 \mathrm{~m}$, and the air curtain should have a speed of $3 \mathrm{~m} / \mathrm{s}$, an angle of $0^{\circ}$, and an opening period of $30 \mathrm{~s}$; additionally, the air curtain's axis must not be bent into the cold room [7].

When it comes to air infiltration into an open showcase freezer, the infiltration of warm air is affected by the wind speed, angle, and height [3]. Changes in the temperature of the open showcase freezer due to the curtain do not affect the infiltration of warm air [4]. This experiment showed that simply adding an air guide bar can make the air curtain stronger. Air can flow from the top supply to the bottom of the freezer without the air curtain breaking. This led to the idea, in this research, that if the direction of the wind is controlled effectively, it could increase the strength of the air curtain. Cold loss tests, considering the losses caused by the opening of cold room doors in industrial plants, should use an air curtain to prevent warm air infiltration [11].

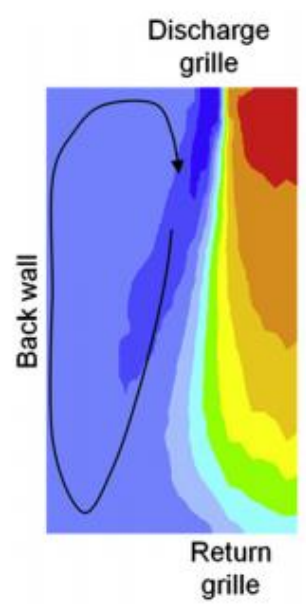

(a)

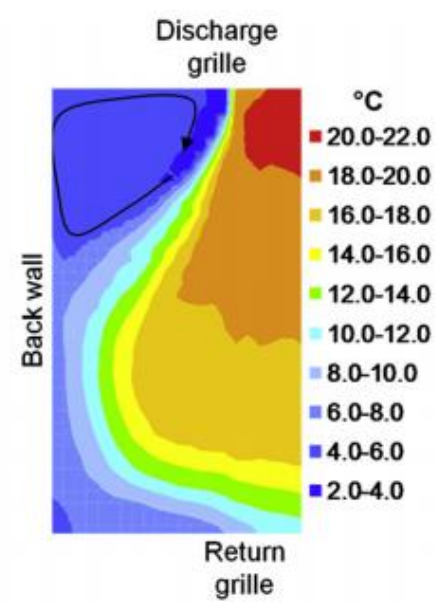

(b)

Fig. 2. Measured temperature profiles through the centre section of a cabinet with a $1200 \mathrm{~mm}$ high curtain with a discharge air grille width of $70 \mathrm{~mm}$ : (a) A sealed curtain with discharge velocity of $2.6 \mathrm{~m} \mathrm{sL1}$; (b) A broken curtain with a discharge velocity of $1.7 \mathrm{~m}$ sL1. The arrow denotes air circulation within the cold cavity [2]

Figure 3 compares the air curtain flow with and without an air guide bar in an open showcase freezer. The use of an air curtain with an air guide bar reduced the average cabinet temperature from $4.7^{\circ} \mathrm{C}$ to $-0.2{ }^{\circ} \mathrm{C}$. The energy used for cooling was reduced by $34 \%$ [5]. 


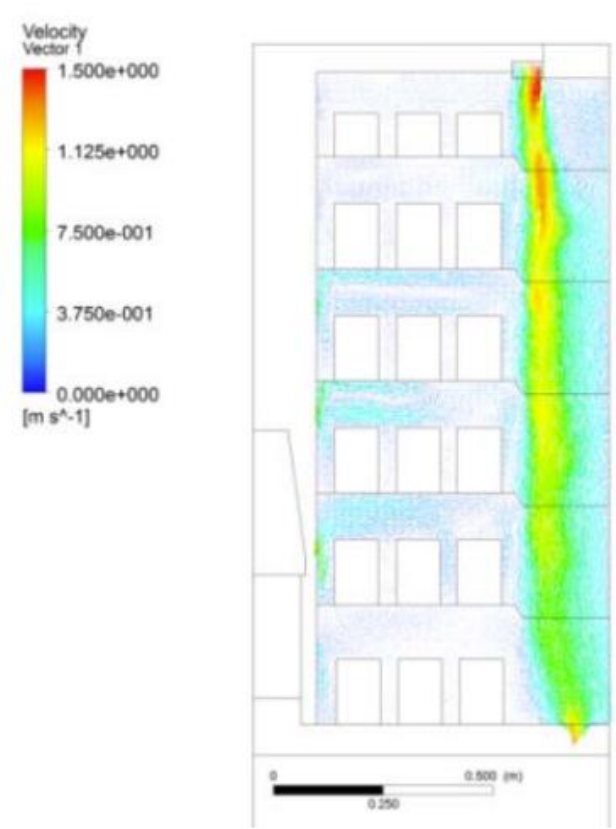

(a)

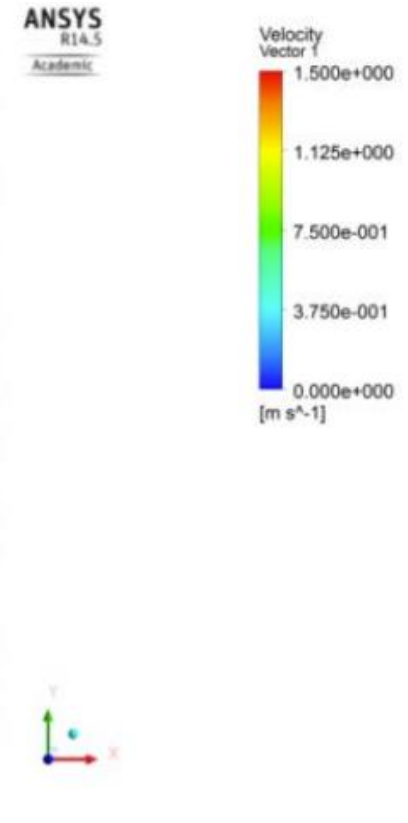

(b)

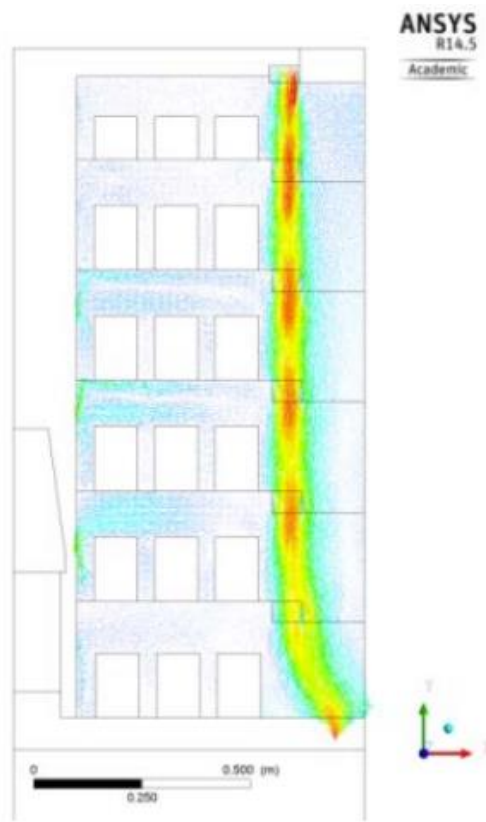

Fig. 3. (a) Air curtain without an air guide bar; and (b) air curtain with an air guide bar. The latter situation will make the air curtain stronger [5]

Figure 4 shows the results of using CFDs to show the temperature and airflow direction more clearly. CFDs have been widely used in research presentations-for example, in the simulation of synthetic jet cooling [18] - in order to visualize the heat transfer more clearly. Alternatively, complex and costly solid oxide fuel cell experiments require dynamic computational fluid simulations. CFDs have been used in many studies; for example, an overview of computational fluid dynamics modelling in solid oxide fuel cells has been presented in [19], and it has been shown that it is easier to see the flow of natural gas pipelines that are difficult to access through use of CFDs [22]. Fluid aerodynamics have been simulated to visualize the performance of various NACA airfoils [23]. Fluid dynamics have been simulated to investigate the performance of a double-stage Savonius rotor [24]. CFDs have also been used to determine the optimal position to install a boat hydrofoil [25], or to visualize the heat transfer inside a pipe [26]. Therefore, researchers have widely used CFDs for simulation research, in order to make the consequent testing easier and more accurate.

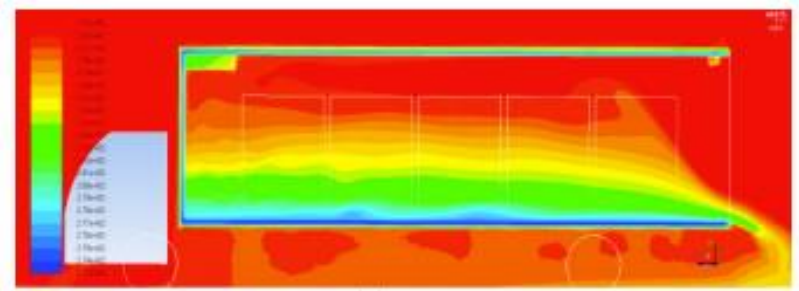

(a)

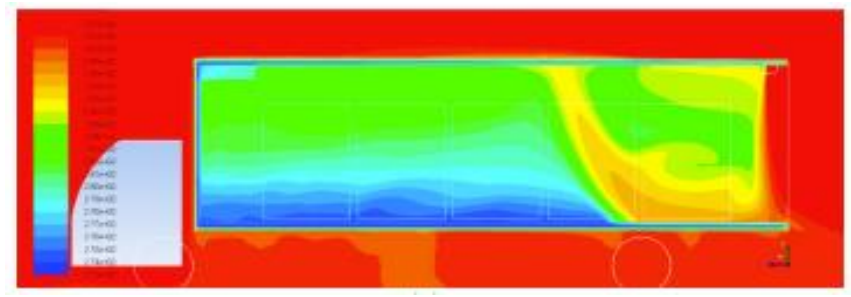

(b)

Fig. 4. (a) Temperature distribution inside a refrigerated truck body without an air curtain; and (b) temperature distribution inside a refrigerated truck body with an air curtain velocity of $5.4 \mathrm{~m} / \mathrm{s}$ [6] 


\section{Methodology}

This research aims to test the air curtain's wind direction by comparing conventional and honeycomb wind grills to determine which grill is more effective at preventing warm air infiltration. The air curtain tested will be used for the Tesco Lotus type of supermarket cold room. The cold room temperature is about 1 to $3^{\circ} \mathrm{C}$ and the outside room temperature is about $27^{\circ} \mathrm{C}$. The experiment was conducted to observe warm air infiltration using CFDs to view the airflow direction and temperature from the air curtain for easy comparison.

\subsection{Domain Geometry}

As shown in Figure 5, the cold room used in the experiment resembled a rectangular box, with internal dimensions of $3 \mathrm{~m} \times 3.1 \mathrm{~m} \times 2.6 \mathrm{~m}(\mathrm{~L} \times \mathrm{W} \times \mathrm{H})$. The insulation thickness, on both the front and back of the floor, as well as the ceiling, was $0.1 \mathrm{~m}$. The size of the cold room door was $2.01 \mathrm{~m} \times$ $0.99 \mathrm{~m}$. The air curtain used in the experiment was $1.05 \mathrm{~m} \times 0.245 \mathrm{~m} \times 0.209 \mathrm{~m}(\mathrm{~L} \times \mathrm{W} \times \mathrm{H})$, and its weight was $14.8 \mathrm{~kg}$. An IP44 enclosure was horizontally installed at the centre, $0.05 \mathrm{~m}$ above the cold room door. The air outlet size was $0.97 \mathrm{~m} \times 0.06 \mathrm{~m}$. The velocity of air leaving the grille averaged about $6 \mathrm{~m} / \mathrm{s}$. An FCU was installed in the upper centre of the cold room wall, with dimensions of 1.28 $\mathrm{m} \times 0.32 \mathrm{~m} \times 0.32 \mathrm{~m}(\mathrm{~L} \times \mathrm{W} \times \mathrm{H})$, having two fans $0.28 \mathrm{~m}$ in diameter. The cold room was located in back-stock, with dimensions of $35 \mathrm{~m} \times 6 \mathrm{~m} \times 6 \mathrm{~m}(\mathrm{~L} \times \mathrm{W} \times \mathrm{H})$. The temperature measurement point outside the cold room was $100 \mathrm{~cm}$ above the floor and $30 \mathrm{~cm}$ away from the door.

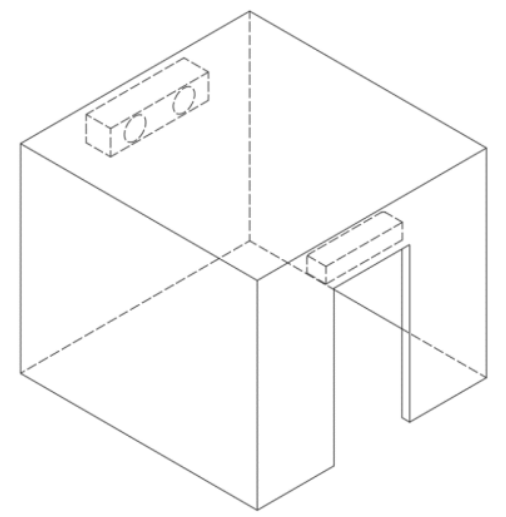

(a)

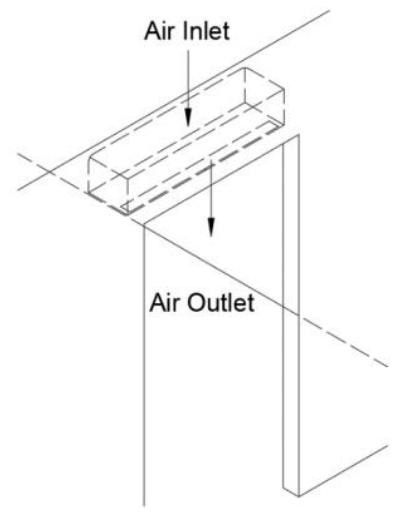

(b)

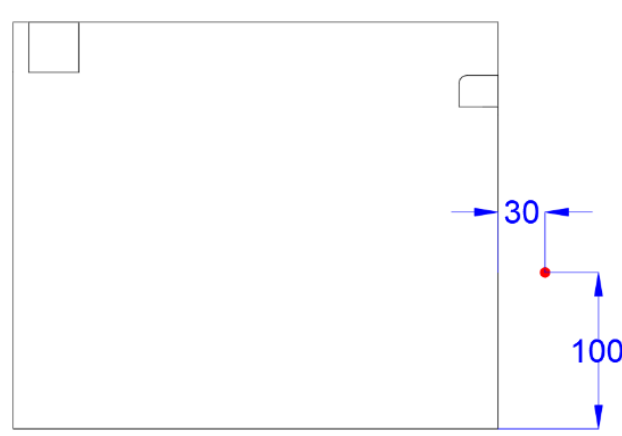

(c)

Fig. 5. (a) Geometry of the cold room; (b) geometry of the air curtain; and (c) temperature point outside of the door

As shown in Figure 6, the typical honeycomb grille used in the test was a $0.1 \mathrm{~cm}$-thick painted steel material comprising a total of five grids, each $85 \mathrm{~cm}$ long with a distance of $1 \mathrm{~cm}$ between them, and a total of four sieve strips. All five grips were fixed perpendicularly. Each piece was installed 27 $\mathrm{cm}$ apart. The honeycomb grille was designed by adding an additional number of mounting strips. There were 33 pieces in total, each $3 \mathrm{~cm}$ apart. It was anticipated that the addition of a grille mounting bar would reduce the turbulence of wind coming out of the grille. 


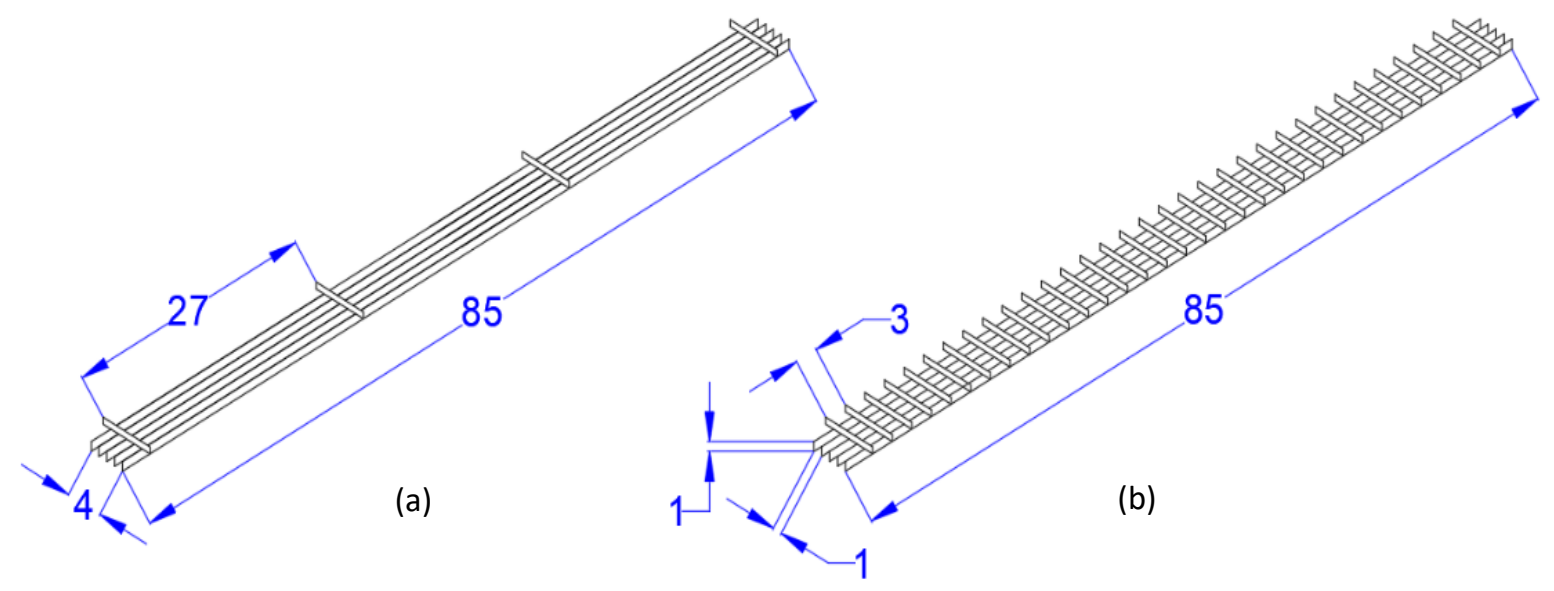

Fig. 6. (a) Dimensions of the common grille ( $\mathrm{cm})$; and (b) dimensions of the honeycomb grille $(\mathrm{cm})$

\subsection{Requirements for CFD}

\subsubsection{Numerical solution procedure}

The SolidWork Flow Simulation software was implemented to calculate the CFD results. The model considered the effect of outdoor air with a temperature of $27{ }^{\circ} \mathrm{C}$, a gravitational pull of 9.81 $\mathrm{m} / \mathrm{s}^{2}$, and an atmospheric pressure defined as 1 bar, in order to take the natural heat of the fluid as the definition of air.

\subsubsection{Boundary, initial, and test conditions}

The FCU was installed behind the cold room, with a blower wind speed of $3.5 \mathrm{~m} / \mathrm{s}$ and an outlet air temperature of $-8{ }^{\circ} \mathrm{C}$, and the air curtain was installed above the cold room entrance door. At 5 $\mathrm{cm}$ above the door, the blower wind speed was $6.5 \mathrm{~m} / \mathrm{s}$ and the outlet air temperature was $1{ }^{\circ} \mathrm{C}$. The air curtain was initially closed, in order to simulate curtainless air heat transfer.

\subsubsection{Mesh independence}

A mesh was created to calculate the domain area, to ensure accuracy in conducting simulations in the area that we were interested in. The mesh used was to be more detailed. In fact, the more meshes defined, the more accurate the simulation [20,21]. However, it was important to take into account whether the amount of detail used for the mesh was appropriate: if the mesh is set to a higher resolution, the result will have a larger file size.

\subsubsection{Global mesh setting}

As shown in Figure 7, a mesh was created, which was used to calculate all common areas. In this research, the mesh slot was set at level 3. 


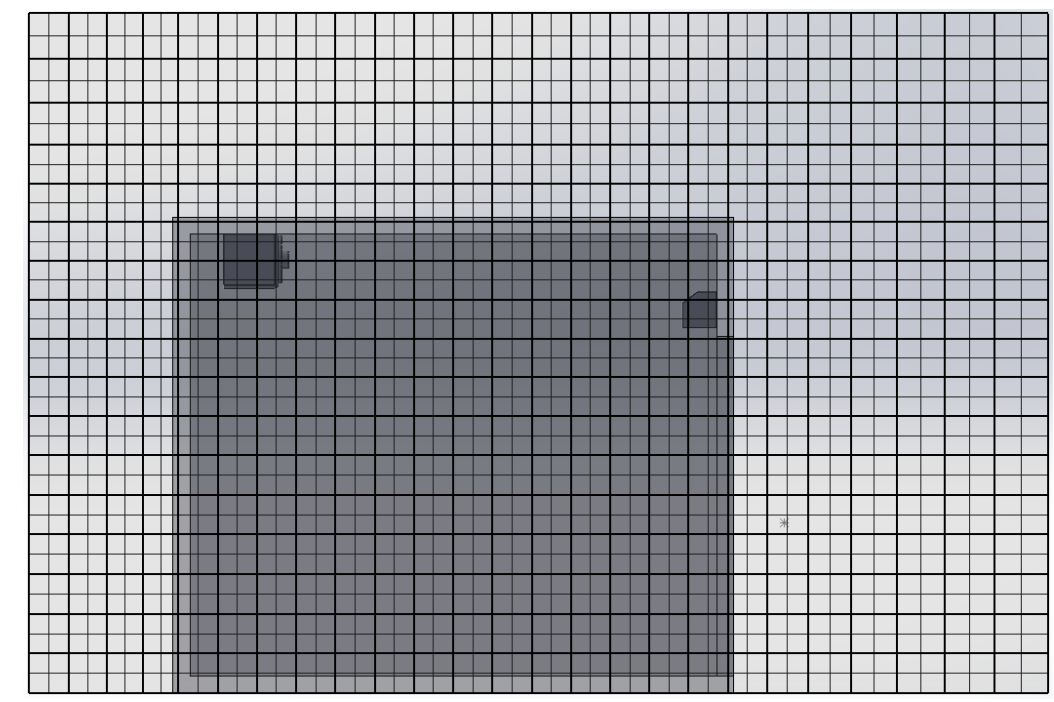

Fig. 7. Global mesh for the cold room

\subsubsection{Local mesh}

As shown in Figure 8 and 9, the mesh was more precisely defined in the moving area for greater computational accuracy. Local meshes were applied at the airflow (in and out) areas of the FCU and at the air curtain. The wind grille area, in particular, needed a high mesh resolution, with the refinement of cells set at level 7.

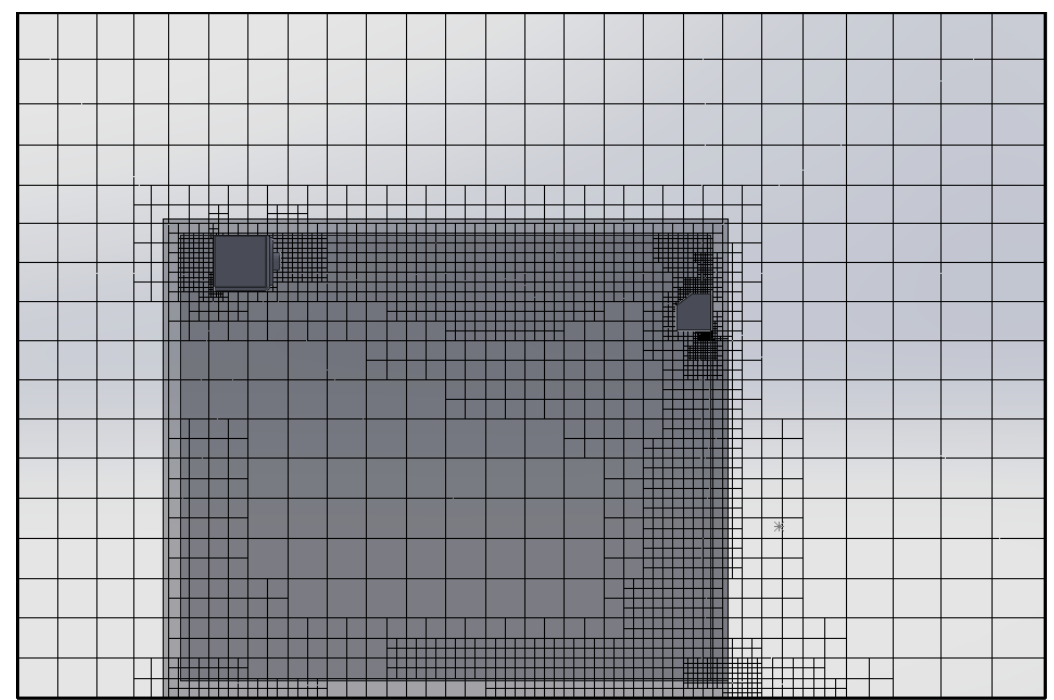

Fig. 8. Mesh used for the cold room with an air curtain 


\section{Results}

\subsection{Infiltration Behaviour Without an Air Curtain}

From Figure 9 and 10, it can be seen that, when the room was cooled to $1{ }^{\circ} \mathrm{C}$ and the door was left with no air curtain for 1 hour, the mean temperature inside the cold room was $9.1{ }^{\circ} \mathrm{C}$, the average temperature in front of the cold room was $26.4{ }^{\circ} \mathrm{C}$, and the average air velocity ranged from 0.3 to $0.4 \mathrm{~m} / \mathrm{s}$.

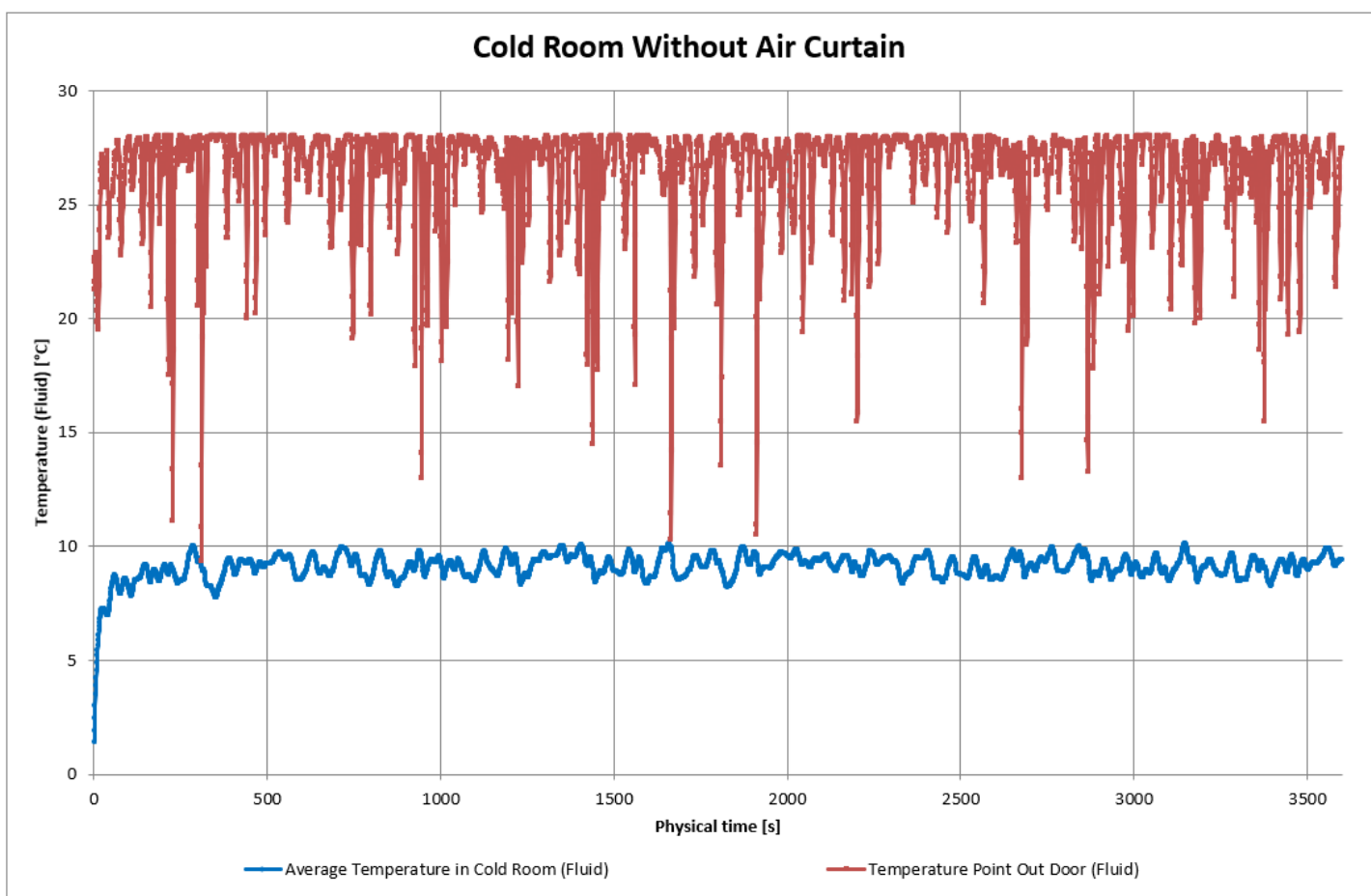

Fig. 9. Temperature for the cold room without an air curtain

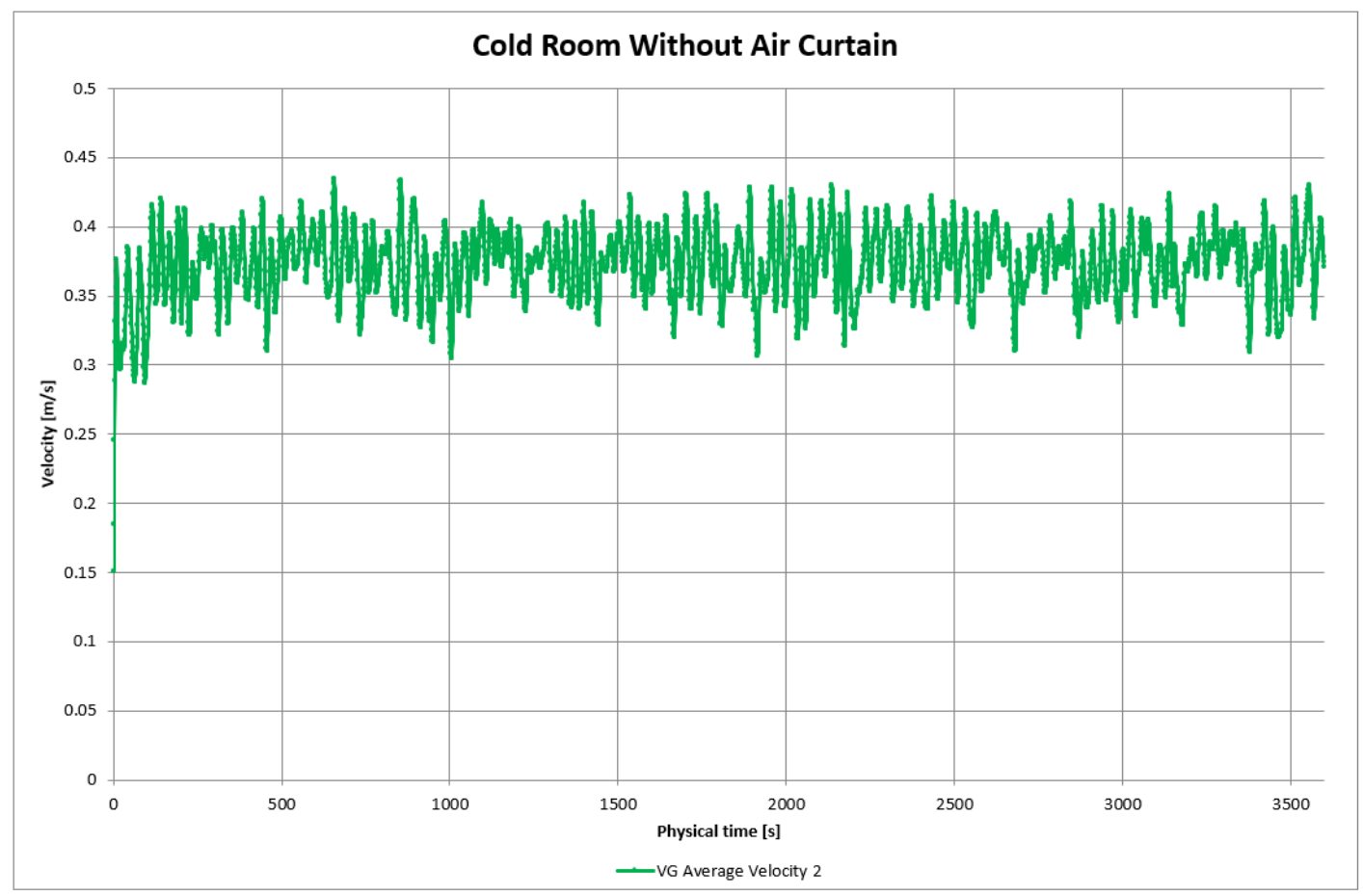

Fig. 10. Velocity for the cold room without an air curtain 


\subsection{Infiltration Behaviour With an Air Curtain Having a Common Grille}

From Figure 11, it can be seen that, when the room was cooled to $10{ }^{\circ} \mathrm{C}$ and the door was left open when using an air curtain having a conventional grille for 1 hour, the mean temperature inside the cold room was $6.781^{\circ} \mathrm{C}$, the average temperature in front of the cold room was $27.93{ }^{\circ} \mathrm{C}$, and the average air velocity in Figure 12 increased from 0.8 to $0.9 \mathrm{~m} / \mathrm{s}$.

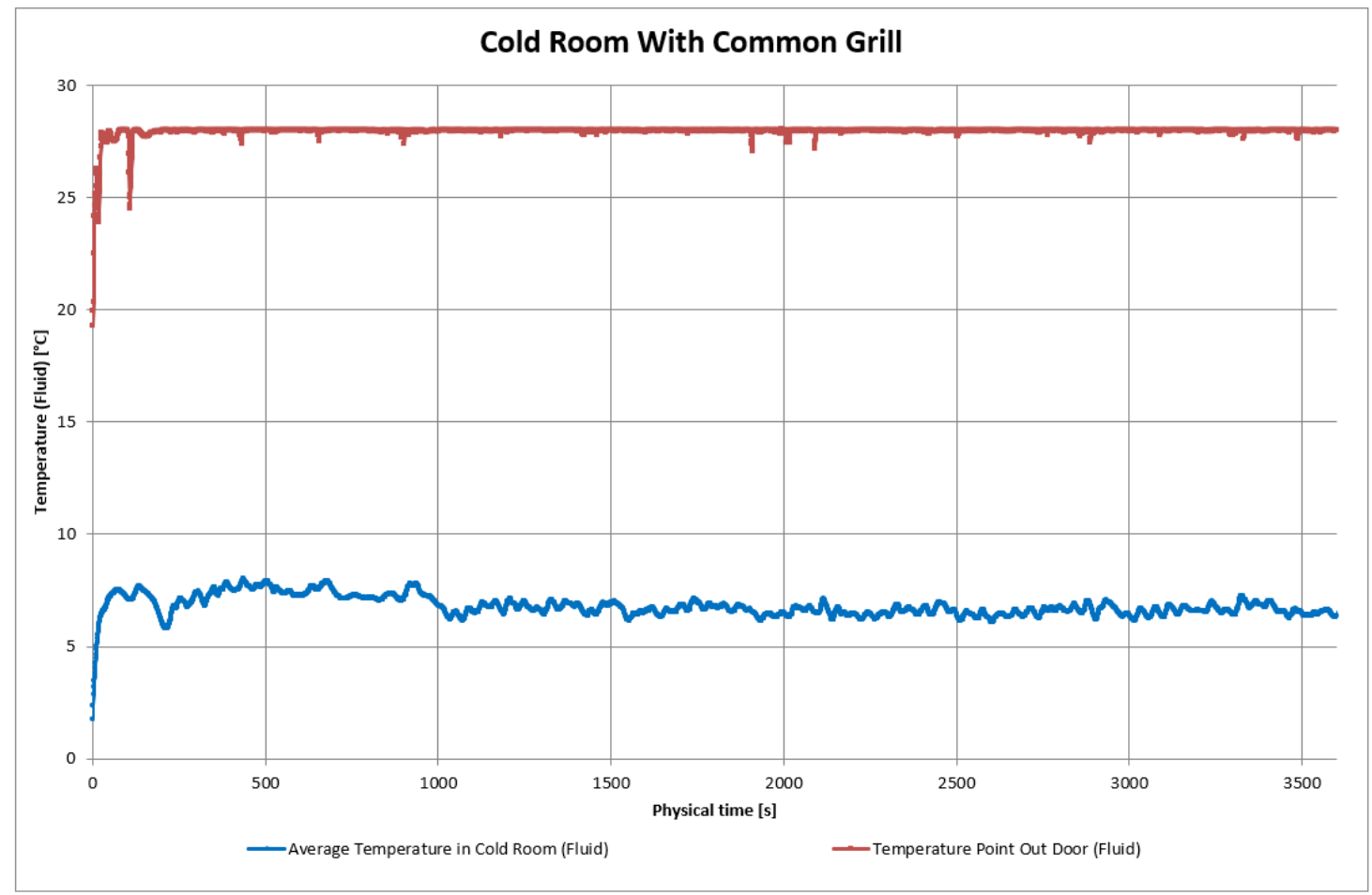

Fig. 11. Temperature of a cold room with an air curtain having a common grille

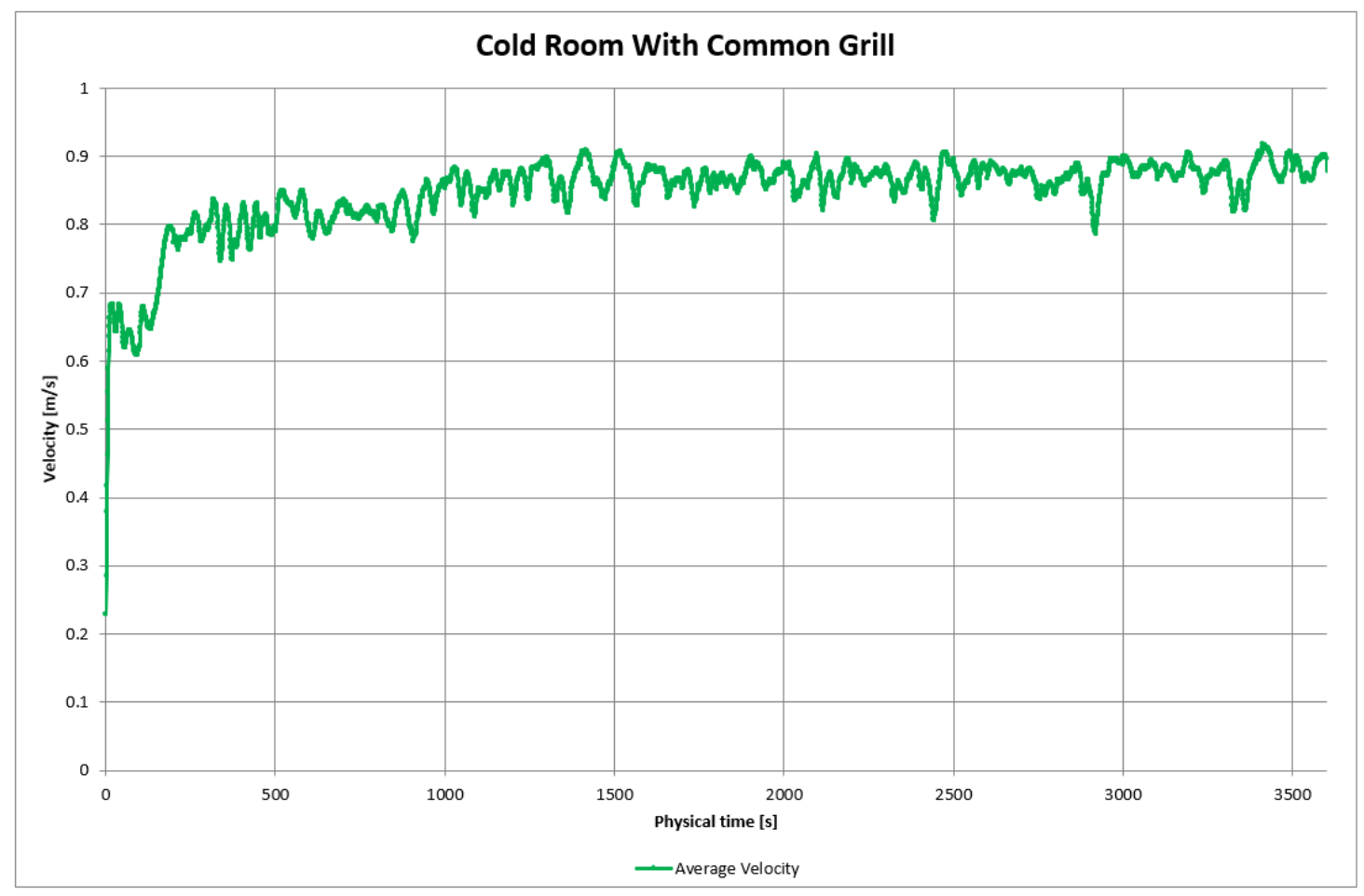

Fig. 12. Velocity for a cold room with an air curtain having a common grille 


\subsection{Infiltration Behaviour With an Air Curtain Having a Honeycomb Grille}

From Figure 13, it can be seen that, when the room was cooled to $1^{\circ} \mathrm{C}$ and the door was left open when using an air curtain having a honeycomb grille for 1 hour, the mean temperature inside the cold room was $6.704{ }^{\circ} \mathrm{C}$, the average temperature in front of the cold room was $27.925{ }^{\circ} \mathrm{C}$, and the average air velocity (Figure 14) - similar to Figure 12 -increased from 0.8 to $0.9 \mathrm{~m} / \mathrm{s}$.

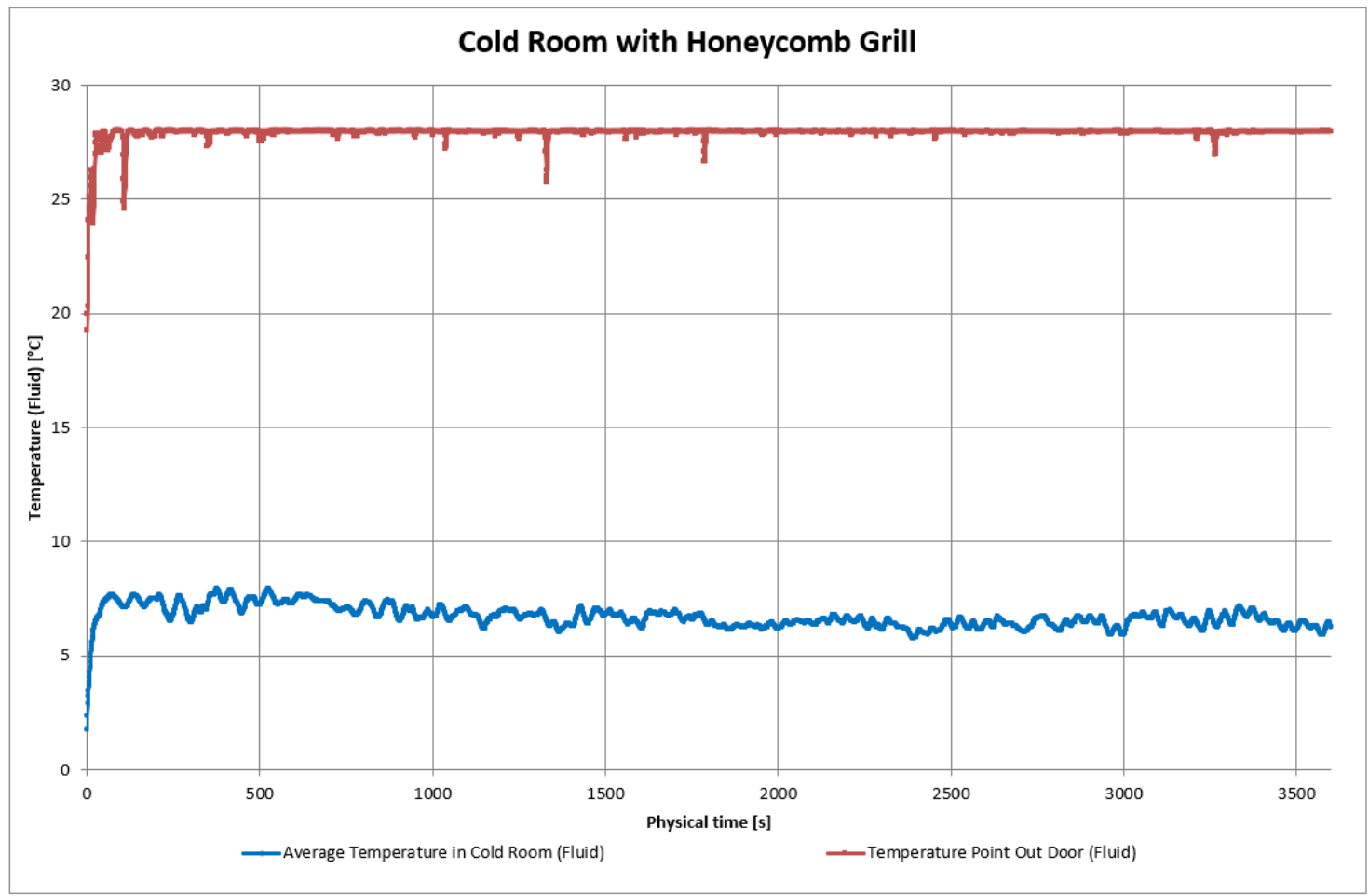

Fig. 13. Temperature of the cold room with an air curtain having a honeycomb grille

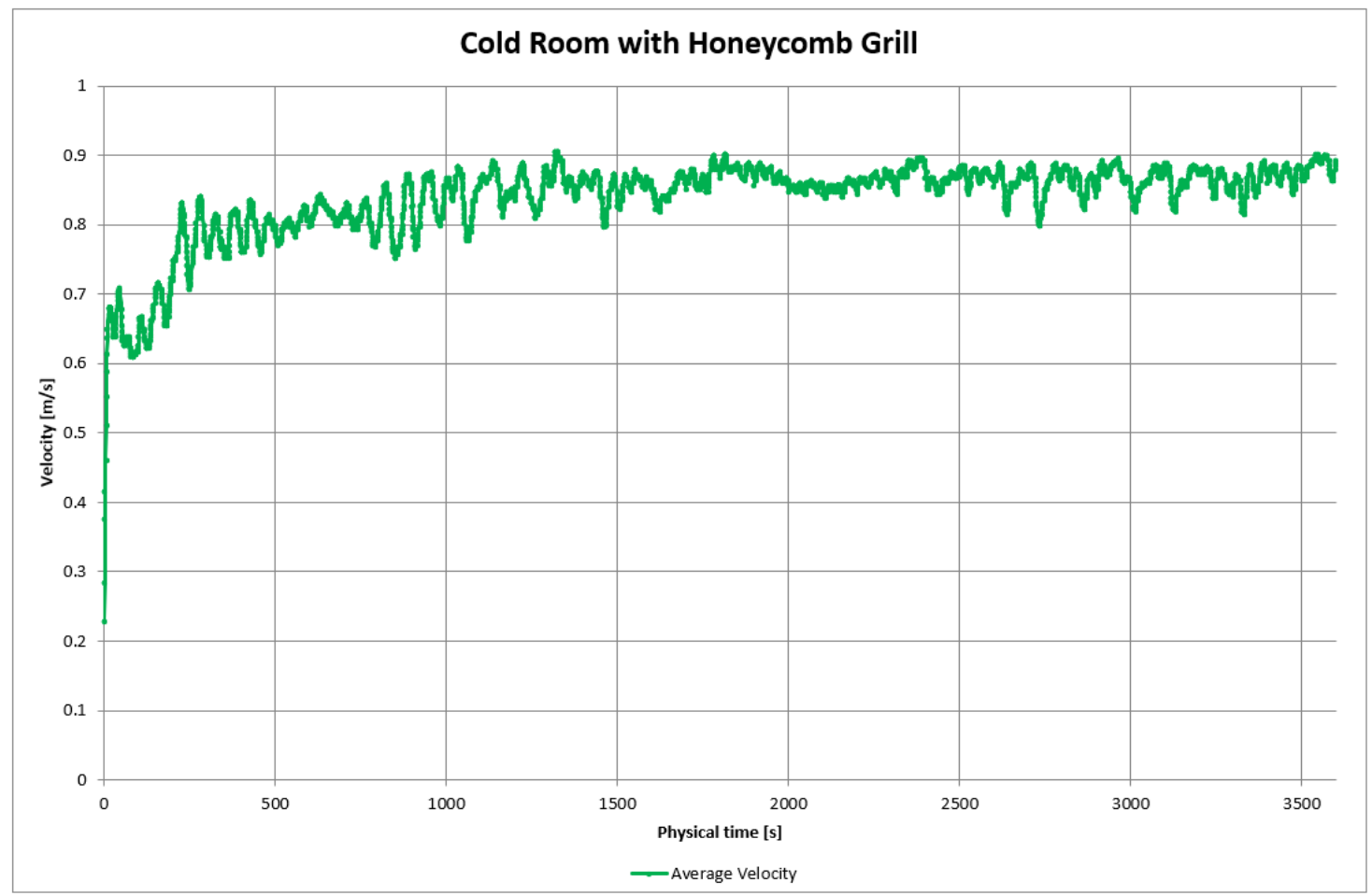

Fig. 14. Velocity for the cold room with an air curtain having a honeycomb grille 


\subsection{CFD Temperature Simulation}

From Figure 15(a) it can be seen that, after $100 \mathrm{~s}$ of simulation, the air in the cold chamber began to flow out. After $5 \mathrm{~m}$ of testing, warm outside air started to flow into the cold room from the top of the door. After $10 \mathrm{~m}$ of testing, the temperature slightly rose. At steady-state, it can be seen that the average temperature in the cold room remained constant, as the FCU continued to cool the cold room. The average temperature inside the cold room was $9.17^{\circ} \mathrm{C}$. As shown in Figure 15 (b), after 100 s of testing, the air curtain (which just started) was weak, as can be observed from the temperature curve around the door. After $5 \mathrm{~m}$ of testing, it can be seen that the air curtain had less internal curvature of the temperature. After $10 \mathrm{~m}$ of testing, the cold room temperature began to drop again. At steady-state, it can be seen that the cooler temperature of the cold room was dispersed in the middle of the cold room; the average temperature inside the cold room was $6.04{ }^{\circ} \mathrm{C}$. In Figure 15 (c), the experiment considering an air curtain having a honeycomb grille showed similar results to that of the air curtain with a common grille. At steady-state, the honeycomb grille was able to distribute the temperature inside the cold room more evenly and at a lower temperature: the average temperature inside the cold room was $5.46{ }^{\circ} \mathrm{C}$.

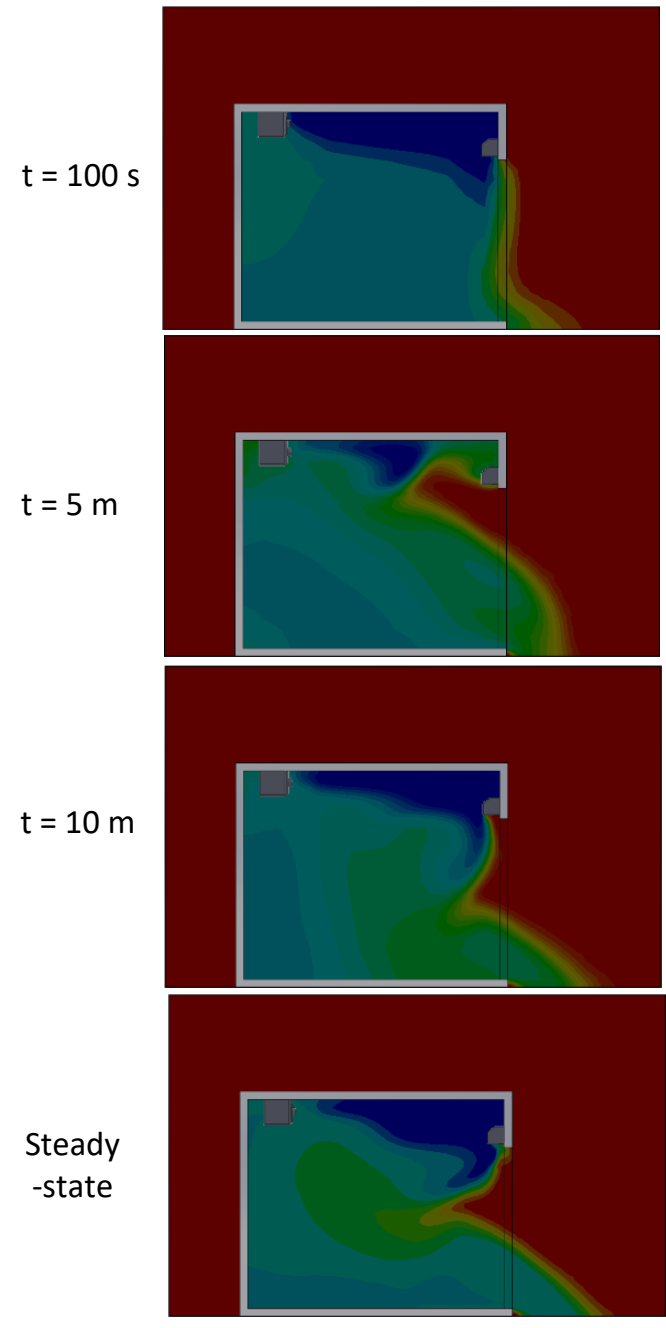

(a) Without air curtain
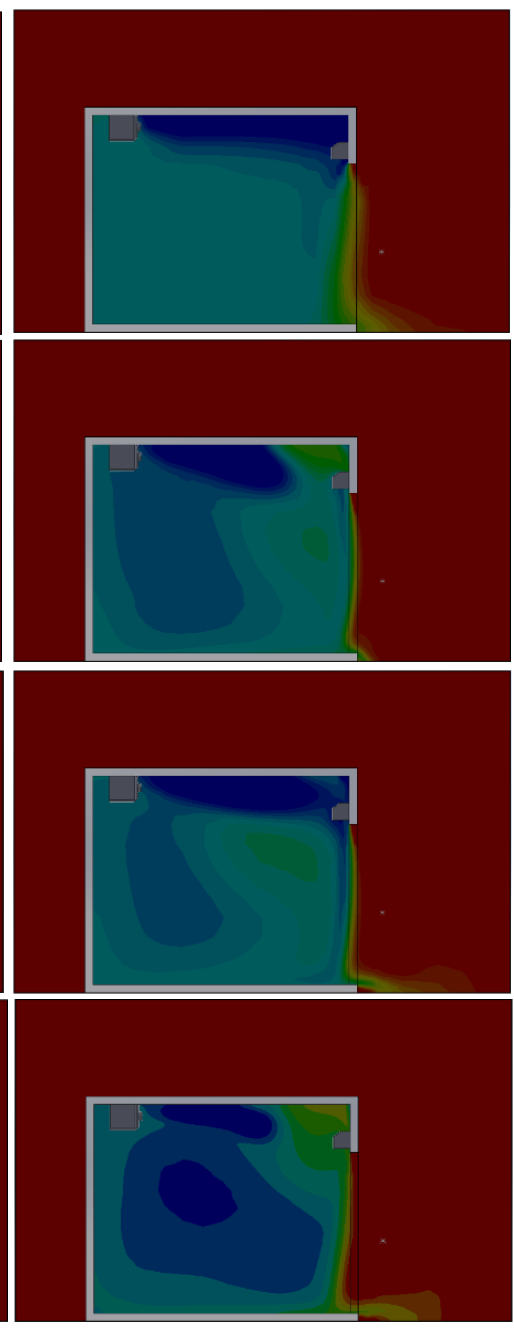

(b) Common grille
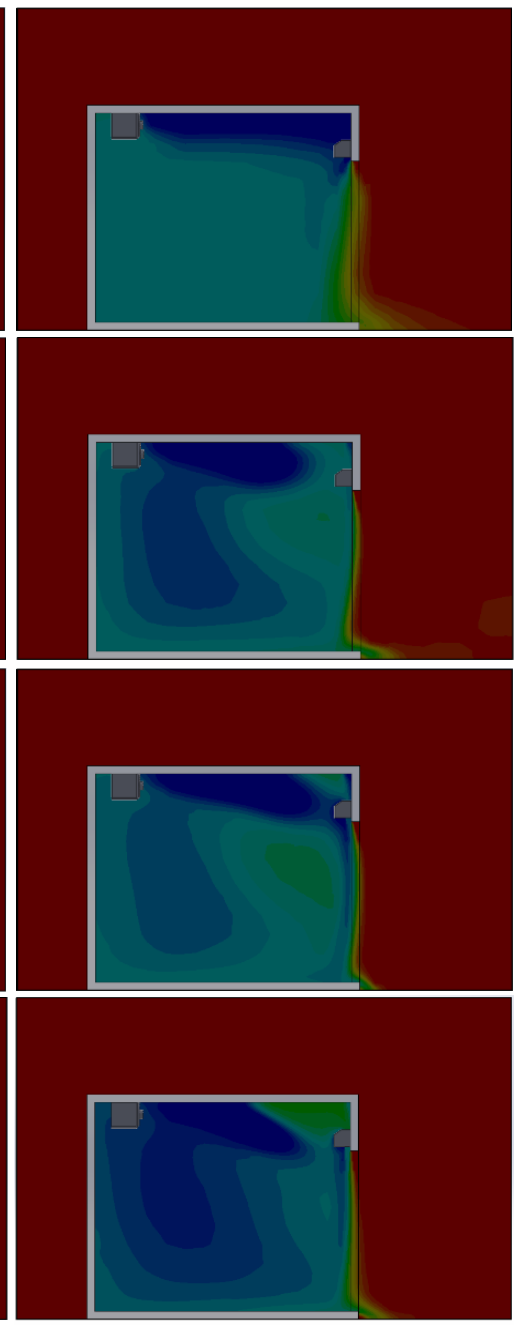

(c) Honeycomb grille

Fig. 15. (a) Temperature in the cold room without an air curtain; (b) temperature in the cold room with an air curtain having a common grille; and (c) temperature in the cold room with an air curtain having a honeycomb grille 


\subsection{CFD Velocity Simulation}

From Figure 16(a), it can be seen that, when the cold room door was open, there was an airflow coming out of the FCU, along with another at the bottom of the outer door. From Figure $16(b)$, when installing an air curtain with a common grille, air flowed from the grille to the bottom of the cold room. When it reached steady-state, the wind direction was slightly inclined towards the inside of the cold room. From Figure 16(c), when installing an air curtain with a honeycomb grille, air flowed from the grille to the bottom of the cold room, as with the common grille. When it reached steadystate, the wind direction was straighter, and did not flow obliquely toward the inside of the cold room.

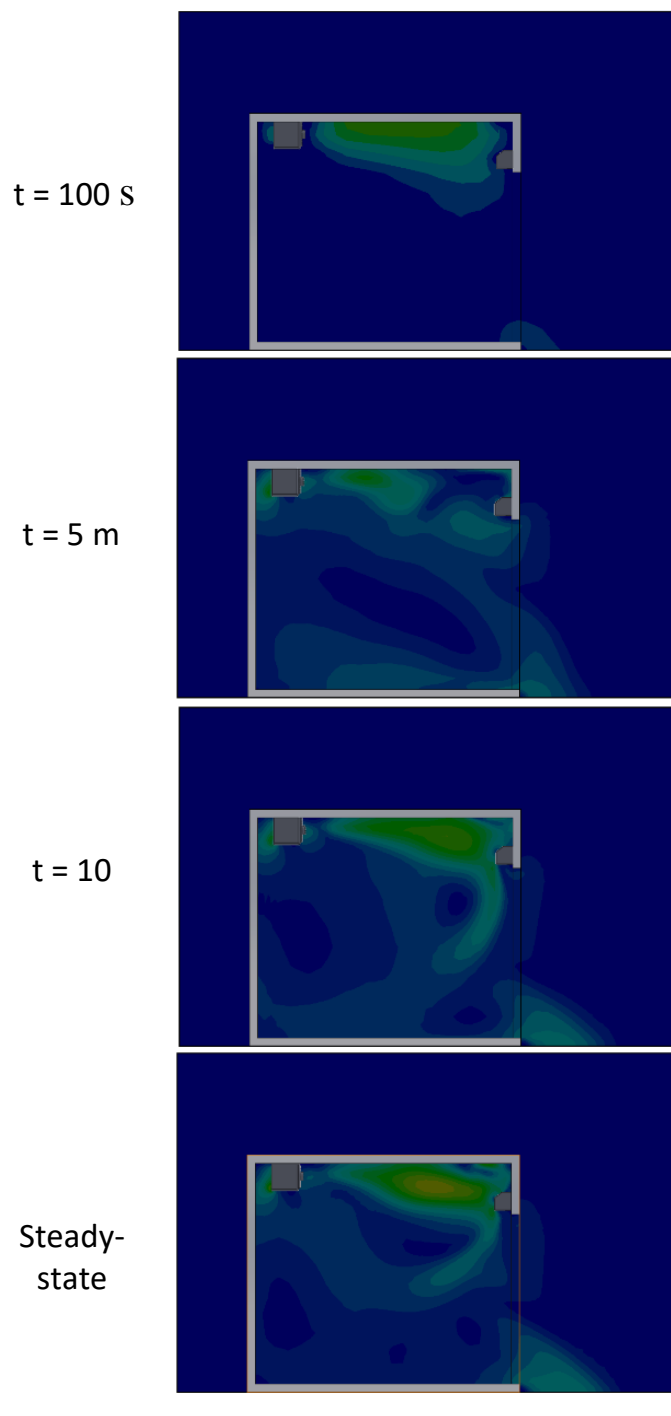

(a) Without an air curtain
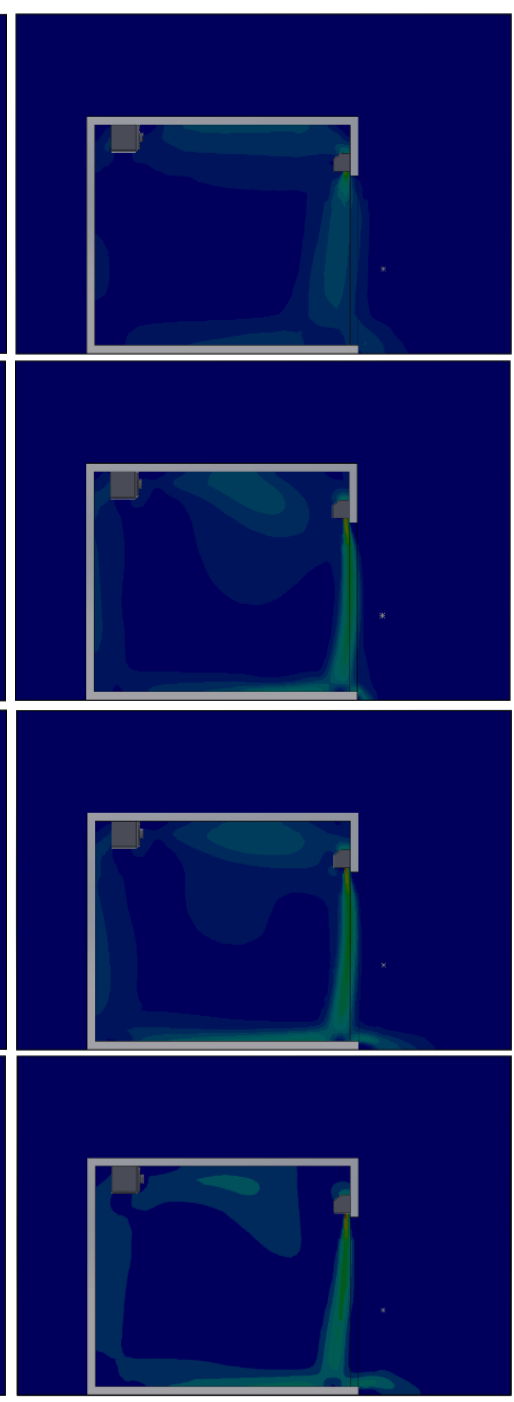

(b) Common grille
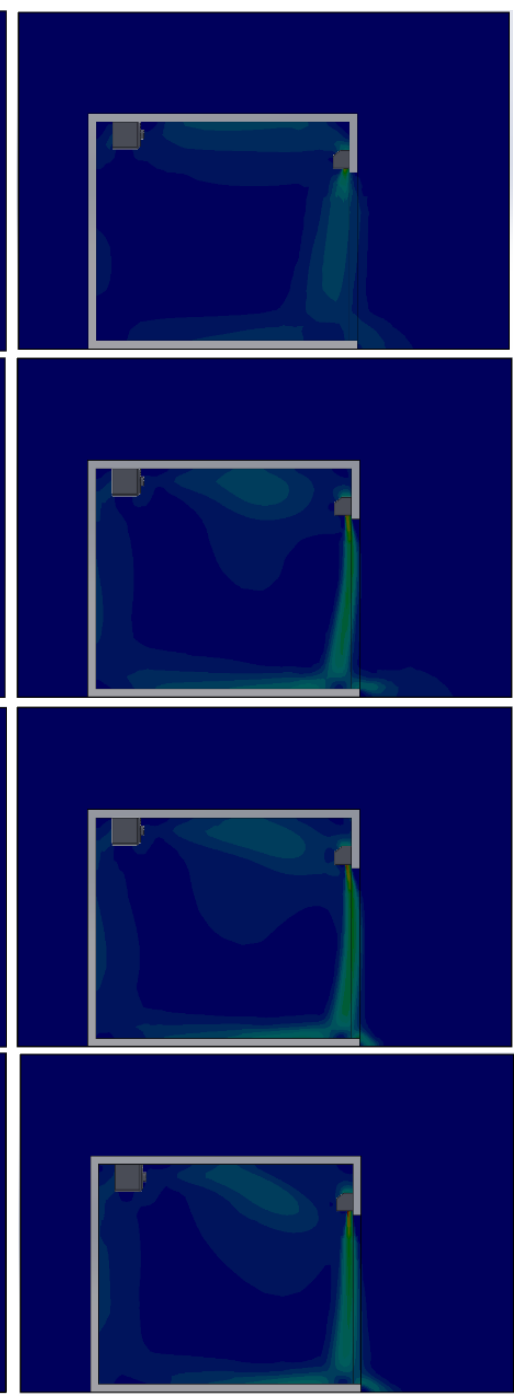

(c) Honeycomb grille

Fig. 16. (a) Velocity in a cold room without an air curtain; (b) velocity in a cold room with an air curtain having a common grille; and (c) velocity in a cold room with an air curtain having a honeycomb grille 


\section{Conclusions}

The first experiment was conducted in a cold room with a temperature of $1{ }^{\circ} \mathrm{C}$, with the cold room door open and the air curtain closed, and with the FCU operating normally. The result was that the temperature in the cold room increased and began to stabilize within $100 \mathrm{~s}$, with an average temperature of $9.17{ }^{\circ} \mathrm{C}$ inside the cold room. The second experiment was carried out in a cold room with a temperature of $1{ }^{\circ} \mathrm{C}$, with the cold room door open and considering an air curtain with a common grille. The result was that, when steady-state conditions were reached, the internal temperature of the cold room was $6.04{ }^{\circ} \mathrm{C}$. The final experiment was carried out in a $1{ }^{\circ} \mathrm{C}$ cold room, with the cold room door open and considering an air curtain having a honeycomb grille. In this experiment, when steady-state conditions were reached, the temperature inside the cold room was $5.46{ }^{\circ} \mathrm{C}$. The results of the comparative experiments between an air curtain having a common grille and one with a honeycomb grille demonstrated that an air curtain with a honeycomb grille can block the air flow through the door better, leading to $10.62 \%$ better temperature retention inside the cold room than when using an air curtain with a common grille.

\section{Acknowledgement}

This research was supported by SANYO S.M.I. (Thailand) Co., Ltd. The authors also acknowledge the financial support received from the Interdisciplinary Graduate School of Energy System, and the Faculty of Engineering at Prince of Songkla University, Hatyai Campus.

\section{References}

[1] Chou, Ding-chin, Ching-Shan Chang, and Yong-Zhi Hsu. "Investigation and analysis of power consumption in convenience stores in Taiwan." Energy and Buildings 133 (2016): 670-687. https://doi.org/10.1016/i.enbuild.2016.10.010

[2] Hammond, Edward, Joe Quarini, and Alan Foster. "Development of a stability model for a vertical single band recirculated air curtain sealing a refrigerated cavity." International journal of refrigeration 34, no. 6 (2011): 14551461. https://doi.org/10.1016/i.ijrefrig.2011.05.001

[3] Amin, Mazyar, Dana Dabiri, and Homayun K. Navaz. "Comprehensive study on the effects of fluid dynamics of air curtain and geometry, on infiltration rate of open refrigerated cavities." Applied thermal engineering 31, no. 14-15 (2011): 3055-3065. https://doi.org/10.1016/j.applthermaleng.2011.05.039

[4] Amin, Mazyar, Dana Dabiri, and Homayun K. Navaz. "Effects of secondary variables on infiltration rate of open refrigerated vertical display cases with single-band air curtain." Applied thermal engineering 35 (2012): $120-126$. https://doi.org/10.1016/j.applthermaleng.2011.10.013

[5] Sun, Jining, Konstantinos M. Tsamos, and Savvas A. Tassou. "CFD comparisons of open-type refrigerated display cabinets with/without air guiding strips." Energy Procedia $123 \quad$ (2017): 54-61. https://doi.org/10.1016/i.egypro.2017.07.284

[6] Rai, Ashika, Jining Sun, and Savvas A. Tassou. "Numerical investigation of the protective mechanisms of air curtain in a refrigerated truck during door openings." Energy Procedia 161 (2019): $216-223$. https://doi.org/10.1016/i.egypro.2019.02.084

[7] Rai, Ashika, Jining Sun, and Savvas A. Tassou. "Three-dimensional investigation on the positioning of air curtain on its effectiveness in refrigerated vehicles used for food distribution." Energy Procedia 161 (2019): 224-231.

[8] Rai, Ashika, Jining Sun, and Savvas A. Tassou. "Numerical investigation into the influence of air curtain discharge angles in refrigerated trucks." Energy Procedia 161 (2019): 207-215. https://doi.org/10.1016/i.egypro.2019.02.083

[9] Gonçalves, J. C., J. J. Costa, and A. M. G. Lopes. "Parametric study on the performance of an air curtain based on CFD simulations-New proposal for automatic operation." Journal of Wind Engineering and Industrial Aerodynamics 193 (2019): 103951. https://doi.org/10.1016/i.jweia.2019.103951

[10] Foster, A. M., M. J. Swain, R. Barrett, P. D’Agaro, L. P. Ketteringham, and S. J. James. "Three-dimensional effects of an air curtain used to restrict cold room infiltration." Applied Mathematical Modelling 31, no. 6 (2007): 1109-1123. https://doi.org/10.1016/i.apm.2006.04.005

[11] Azzouz, A., J. Gosse, and M. Duminil. "Experimental determination of cold loss caused by opening industrial coldroom doors. International Journal of Refrigeration, (1992):57-66. 
[12] Saengsikhiao, Piyanut, Juntakan Taweekun, Kittinan Maliwan, Somchai Sae-ung, and Thanansak Theppaya. "The Performance Simulation of The New R463A HFC/HFO/Carbon Dioxide Refrigerant with Lower GWP, As an Alternate Option for The R404A Refrigeration System." Journal of Advanced Research in Fluid Mechanics and Thermal Sciences 76, no. 1 (2020): 113-123. https://doi.org/10.37934/arfmts.76.1.113123

[13] Saengsikhiao, Piyanut, Juntakan Taweekun, Kittinan Maliwan, Somchai Sae-ung, and Thanansak Theppaya. " Development of Environmentally Friendly and Energy Efficient Refrigerants for Refrigeration Systems." (2021): 411-433. https://doi.org/10.32604/EE.2021.012860

[14] Saengsikhiao, Piyanut, Juntakan Taweekun, Kittinan Maliwan, Somchai Sae-ung, and Thanansak Theppaya. "Investigation and analysis of R463A as an alternative refrigerant to R404A with lower global warming potential." Energies 13, no. 6 (2020): 1514. https://doi.org/10.3390/en13061514

[15] Saengsikhiao, Piyanut, Juntakan Taweekun, Kittinan Maliwan, Somchai Sae-ung Sae-ung, and Thanansak Theppaya. "The replacement of the R404A refrigeration system with the environmentally friendly R448A, to improve convenience store energy efficiency in Thailand." Journal of Advanced Research in Fluid Mechanics and Thermal Sciences 75, no. 1 (2020): 137-146. https://doi.org/10.37934/arfmts.75.1.137146

[16] Saengsikhiao, Piyanut, and Juntakan Taweekun. "Energy Efficiency Improvement Solutions for Supermarkets by Low-E Glass Door and Digital Semi-Hermetic Compressor." Energies14, no. 11 (2021): 3134. https://doi.org/10.3390/en14113134

[17] Saengsikhiao, Piyanut, Juntakan Taweekun, Kittinan Maliwan, Somchai Sae-ung, and Thanansak Theppaya. "The improvement of energy efficiency for refrigeration system in Thailand convenience store by digital scroll compressor." Journal of Advanced Research in Fluid Mechanics and Thermal Sciences 74, no. 1 (2020): $144-150$. https://doi.org/10.37934/arfmts.74.1.144150

[18] Ariffin, Ahmad Hamdan, and Kamarul Ariffin Ahmad. "Computational Fluid Dynamic (CFD) Simulation of Synthetic Jet Cooling: A Review." Journal of Advanced Research in Fluid Mechanics and Thermal Sciences 72, no. 2 (2020): 103-112.

[19] Nurul Ashikin Mohd Nazrul Aman, Andanastuti Muchtar, Mahendra Rao Somalu, Masli Irwan Rosli, and Noor Shieelar Kalib. "Overview of Computational Fluid Dynamics Modelling in Solid Oxide Fuel Cell." Universiti Kebangsaan Malaysia (2020): 174-181.

[20] Nurul Azihan Ramli, Azlin Mohd Azmi, Ahmad Hussein Abdul Hamid, Zainal Abidin Kamarul Baharin, Tongming Zhou (2021). "Effect of Cylinder Gap Ratio on The Wake of a Circular Cylinder Enclosed by Various Perforated Shrouds." School of Mechanical Engineering, College of Engineering, University Teknologi Malaysia (2021): 51-68. https://doi.org/10.37934/cfdl.13.4.5168

[21] Salleh, Nursyaira Mohd, Mohamad Shukri Zakaria, Mohd Juzaila Abd Latif, and Adi Azriff Basri. "A Computational Study of a Passive Flow Device in a Mechanical Heart Valve for the Anatomic Aorta and the Axisymmetric Aorta." CFD Letters 13, no. 4 (2021): 69-79. https://doi.org/10.37934/cfdl.13.4.6979

[22] Rabby, Md Insiat Islam, Siti Ujila Masuri, Ahmad Syakir Fariz Samsul Kamal, Zulkiflle Leman, Abdul Aziz Hairuddin, and Nuraini Abdul Aziz. "Flow Characteristics of Disk Bypass Pipeline Inspection Gauge (PIG) in Natural Gas Pipelines using Computational Fluid Dynamics." CFD Letters 13, no. 4 (2021): 11-37. https://doi.org/10.37934/cfdl.13.4.1137

[23] Loutun, Mark Jason Thomas, Djamal Hissein Didane, Mohd Faizal Mohideen Batcha, Kamil Abdullah, Mas Fawzi Mohd Ali, Akmal Nizam Mohammed, and Lukmon Owolabi Afolabi. "2D CFD Simulation Study on the Performance of Various NACA Airfoils." CFD Letters 13, no. 4 (2021): 38-50. https://doi.org/10.37934/cfdl.13.4.3850

[24] Halmy, Muhammad Syahmy Mohd, Djamal Hissein Didane, Lukmon Owolabi Afolabi, and Sami Al-Alimi. "Computational Fluid Dynamics (CFD) Study on the Effect of the Number of Blades on the Performance of DoubleStage Savonius Rotor." CFD Letters 13, no. 4 (2021): 1-10. https://doi.org/10.37934/cfdl.13.4.110

[25] Budiyanto, Muhammad Arif, Naufal Yudha Prawira, and Haekal Dwiputra. "Lift-to-Drag Ratio of the Application of Hydrofoil With Variation Mounted Position on High-Speed Patrol Vessel." CFD Letters 13, no. 5 (2021): 1-9. https://doi.org/10.37934/cfdl.13.5.19

[26] Harish Fekadu, Birlie, and H. V. Harish. "Numerical Studies on Thermo-Hydraulic Characteristics of Turbulent Flow in a Tube with a Regularly Spaced Dimple on Twisted Tape." CFD Letters 13, no. 8 (2021): 20-31. https://doi.org/10.37934/cfdl.13.8.2031 